\title{
High-Affinity Copper Transport and Snq2 Export Permease of Saccharomyces cerevisiae Modulate Cytotoxicity of PR-10 from Theobroma cacao
}

\author{
Cristina Pungartnik, ${ }^{1}$ Aline Clara da Silva, ${ }^{2}$ Sarah Alves de Melo, ${ }^{1,2}$ Karina Peres Gramacho, ${ }^{3}$ \\ Júlio Cézar de Mattos Cascardo,, ${ }^{2}$ Martin Brendel, ${ }^{1}$ Fabienne Micheli, ${ }^{2,4}$ and Abelmon da Silva Gesteira ${ }^{2}$ \\ ${ }^{1}$ UESC, Centro de Biotecnologia e Genética, Laboratório de Biologia de Fungos, Rodovia Ilhéus-Itabuna, km 16, \\ 45650-000 Ilhéus-BA-Brasil; ' $U E S C$, Centro de Biotecnologia e Genética, Laboratório de Biologia Molecular, \\ Rodovia Ilhéus-Itabuna, km 16, 45650-000 Ilhéus-BA-Brasil; ${ }^{3}$ CEPLAC/CEPEC, Cocoa Research Center, \\ 45600-970 Itabuna-BA-Brasil; ${ }^{4}$ CIRAD, UMR DAP, Avenue Agropolis TA96/03, 34398 Montpellier cedex 5, France
}

Submitted 24 January 2008. Accepted 5 September 2008.

\begin{abstract}
A pathogenesis-related (PR) protein from Theobroma cacao (TcPR-10) was identified from a cacao-Moniliophthora perniciosa interaction cDNA library. Nucleotide and amino acid sequences showed homology with other PR-10 proteins having P loop motif and Betv1 domain. Recombinant TcPR-10 showed in vitro and in vivo ribonuclease activity, and antifungal activity against the basidiomycete cacao pathogen $M$. perniciosa and the yeast Saccharomyces cerevisiae. Fluorescein isothiocyanate-labeled TcPR-10 was internalized by $M$. perniciosa hyphae and $S$. cerevisiae cells and inhibited growth of both fungi. Energy and temperature-dependent internalization of the TcPR-10 suggested an active importation into the fungal cells. Chronical exposure to TcPR-10 of 29 yeast mutants with single gene defects in DNA repair, general membrane transport, metal transport, and antioxidant defenses was tested. Two yeast mutants were hyperresistant compared with their respective isogenic wild type: ctr3 $\Delta$ mutant, lacking the high-affinity plasma membrane copper transporter and mac1 1 , the copper-sensing transcription factor involved in regulation of high-affinity copper transport. Acute exposure of exponentially growing yeast cells revealed that TcPR-10 resistance is also enhanced in the Snq2 export permease-lacking mutant which has reduced intracellular presence of TcPR-10.
\end{abstract}

Pathogenesis-related (PR) proteins are defined as plant proteins that are induced in response to pathogen infection or under different stress conditions (van Loon and van Strien 1999; van Loon et al. 1994, 2006). PR proteins have been first grouped into 14 families on the basis of sequence similarity and enzymatic activities (van Loon and van Strien 1999) and more recently reclassified in 17 families based on their primary structure, serological relationships, and biological activities (Christensen et al. 2002). Main attention was paid to some PR proteins such as chitinases and glucanases concerning their fundamental role in degradation of the pathogen's cell

Corresponding author: Fabienne Micheli; Fax: +55 73 3680-5226; E-mail: fabienne.micheli@cirad.fr

Current address of A. C. da Silva: Centro de Pesquisas Gonçalo Moniz, Salvador-Bahia-Brasil.

This article is dedicated to the memory of Juliana Clara da Silva, who participated in this work and tragically died in winter 2006. wall (Mauch et al. 1988) while others, such as members of the PR-10 family, have been studied more recently (Liu and Ekramoddoullah 2006).

The PR-10 family comprises acidic proteins with a low molecular mass (15 to $19 \mathrm{kDa}$ ), lacking peptide signal and resistant to proteases (Liu and Ekramoddoullah 2006; Walter et al. 1990); they are allocated to two distinct groups: intracellular PR proteins (IPR) with homology to ribonucleases (van Loon et al. 1994) and S-norclaurine synthases (Samanani et al. 2004). As biological functions, the PR-10 show enzymatic activity in plant secondary metabolism, play a role in abiotic stress, and have in vitro ribonuclease and antimicrobial activity (Liu and Ekramoddoullah 2006). Many genes encoding PR-10 proteins appear to be regulated according to biotic stresses in a number of plant species. Pathogens triggering a PR-10 response include viruses (Park et al. 2004; Xu et al. 2003), bacteria (Breda et al. 1996; Esnault et al. 1993), and fungi (Colditz et al. 2007; Ekramoddoullah et al. 1998; Liu et al. 2003, 2005; McGee et al. 2001; Tanabe et al. 2006).

Recently, a PR-10 gene from cacao $(T c P R-10)$ was isolated from a Theobroma cacao L.-Moniliophthora (= Crinipellis) perniciosa interaction cDNA library. The hemibiotrophic basidiomycete Moniliophthora perniciosa, the causal agent of witches' broom disease (Aime and Phillips-Mora 2005), is a serious threat to cacao production in South America and the Caribbean (Andebrhan et al. 1999). In planta and in vitro $M$. perniciosa presents two distinct stages: a biotrophic and a necrotrophic or saprotrophic phase. Initially, uninucleated basidiospores germinate on rapidly growing tissues, such as meristems, initiating the biotrophic phase of the disease that is characterized by the presence of monokaryotic intercellular mycelia that lack clamp connections. When emerging branches are infected, the disease is characterized by a rapid growth of new shoots with short internodes, called green brooms (Silva et al. 2002). After some weeks, the infected tissues begin to senesce and are colonized intracellularly by the saprotrophic mycelium of $M$. perniciosa, which is dikaryotic and has clamp connections. The senescing brooms turn brown, forming necrotic dry broom structures typical for witches' broom, which begin to produce basidiocarps releasing basidiospores, thus completing the fungal life cycle (Ceita et al. 2007; Garcia et al. 2007; Silva et al. 2002). Recent studies have shown that it is possible to maintain biotrophiclike mycelium in vitro, and that the conditions that prevent phase change are a low nutrient content and the presence of 
glycerol as the only carbon source (Meinhardt et al. 2006). Breaking mono- and dikaryotic mycelium of $M$. perniciosa yields small cell aggregates that perform as "quasi single cells" (and grow on agar surfaces to so-called pseudocolonies) and, thus, may be used for quantitative toxicity assays (Filho et al. 2006).

Because cacao is an important commodity-20 million people depend directly on cocoa for their livelihood, and approximately $90 \%$ of the production is exported in the form of beans or semimanufactured cocoa products to Europe and the United States (Food and Agriculture Organization)—and because of the drastic impact of witches' broom disease on cacao production, we focused our attention on gene $T c P R-10$ as a candidate for disease control as well as to study the mechanisms of fungal resistance to this PR protein. Here, we report the molecular cloning of $T c P R-10$, the heterologous expression of the corresponding recombinant protein, and its antifungal activity against two different and unrelated species (M. perniciosa and Saccharomyces cerevisiae). We also report results suggesting that resistance to TcPR-10 in S. cerevisiae is related to absence of high-affinity copper transport and $\mathrm{ABC}$ export permease Snq2, a multidrug efflux pump in yeast.
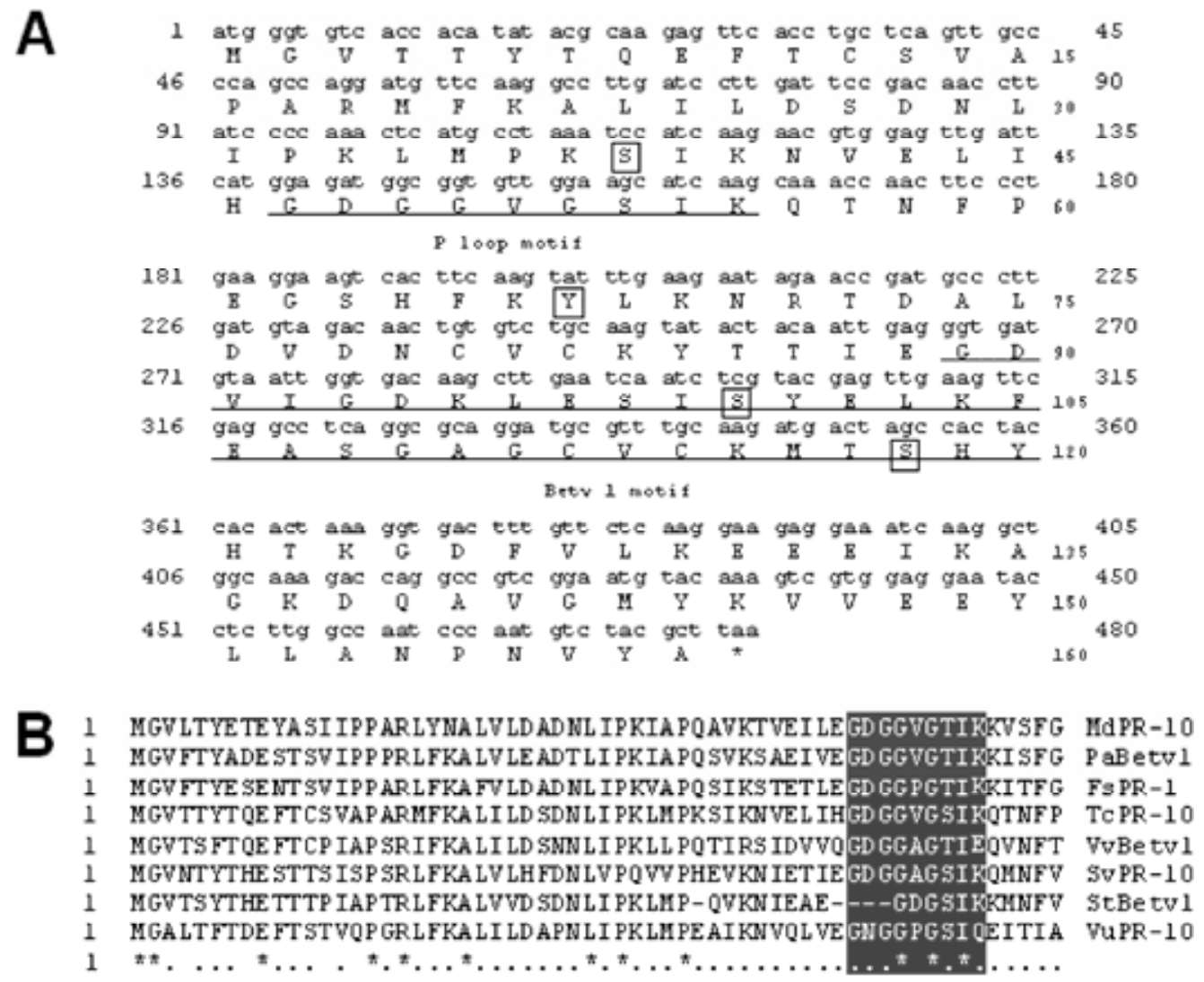

61 EG SE YNYVKHKVE GIDKDN FVYSYSL IE GD AI SD KI D̄KI SYEI KL VA SGSG-SI IKNI SH KdPR-10 61 EGSHYS YVKHRID GLDKDNFVYSYSL VE GD AL SD KV $2 K I$ SYEI KL VASADGGSI IKSTSN PaB ETV1 61 EGSO FKYVKHRIDEVDQ ANFSYGYSVIE GDVVSGII RKI SYEIKI VASPDGGSL LKSTSK FSPR-1 61 EGSH FKYL KNRTD AL DVDNCV CKYTT IE GDVI GD KL SI SYEL KFEA SG-AGCVCKMTSH TCPR-10 61 EA SN LKYVKHO IEEL DKEN FV CKYRH IE GDVL GEELSI AHEVKFEAAD-GGSI CKMASE VVB EVV 1 61 EGGP IKYL KHK IHVI DD KN LE TKYSL IE GD VL GD KLDSI NYDI KFEA SGDGGCVCKTTTE SVPR-10 56 EGSP IKYL KHK IHVVDD KN LVTKYSH IE GDVL GD KLSSI SYDL KFEAHGMGGCVCKSITE \$ EBetV1 61 EGDKIKHL KHRID AIDP EKLTYSYAVIE GD GA LE KVDSI SHEIKFEATEEGGCKTKNVST VUPR-10 $61^{\star} \ldots \ldots{ }^{\star} \ldots \ldots{ }^{\star} \ldots \ldots{ }^{\star} \ldots{ }^{\star} \ldots{ }^{\star} \ldots \ldots .{ }^{\star} \ldots{ }^{\star} \ldots{ }^{\star} \ldots \ldots \ldots{ }^{\star} \ldots$

\begin{tabular}{|c|c|c|}
\hline 0 & & \\
\hline 121 & YHTT GD VE IKEED VKAGKE KA TGLFKLI & $\mathrm{PaBe}$ \\
\hline 121 & YH IKGNHE IKEEE VKAGKE KA AG L FKAV & FsPR-1 \\
\hline 120 & YHTKGD FV LKEEE IKAGKD QA VGIYKV & TCPR. \\
\hline 120 & YHTKGK FE IKEEE IKAGKARA HGI YKV & VvBet \\
\hline 1 & YHTKGD HV ITEEEDNVGKD KA INL FK. & SVPR- \\
\hline & YHTKGD YV LKDEE HNEG OKOGMEL FF & StBet \\
\hline & YH PKAG VE VKEED FKAAKDEG & VuPR- \\
\hline & $\cdots$ & \\
\hline
\end{tabular}

Fig. 1. Nucleotide and amino acid sequences of Theobroma cacao pathogenesis-related (PR) protein 10 (TcPR-10). A, Nucleotide and deduced amino acid sequence of TcPR-10. P loop motif and Betv1 domain are underlined. Asterisk represents open reading frame termination codon. Putative phosphorylation sites are indicated in boxes on the amino acid sequence B, Comparison of predicted amino acid sequence of TcPR-10 with those of VvBetv1 (Vitis vinifera; CAN79554), SvPR-10 (Solanum virginianum; AAU00066), MdPR-10 (Malus $\times$ domestica; AAS00047), StBetv1 (S. tuberosum; AAA03019), PaBetv1 (Prunus avium; AAS47036), FsPR-1 (Fagus sylvatica, AJ130889), and VuPR-10 (Vigna unguiculata, AB038691). The $\mathrm{P}$ loop motif $\left(\mathrm{G}_{47}-\mathrm{K}_{55}\right), \mathrm{E}_{97}, \mathrm{E}_{149}$, and $\mathrm{Y}_{151}$ (as positioned in TcPR-10) involved in ribonuclease activity are indicated in gray boxes. Gaps introduced to get the best alignment are indicated by dashes, and (.) and (*) represent identical and highly conserved amino acids between sequences, respectively. 


\section{RESULTS}

TcPR-10 sequence analysis.

A clone from a cacao-M. perniciosa cDNA library was identified as a putative $P R-10$ gene (insert size of $779 \mathrm{bp}$ ) with an open reading frame (ORF) of 480 nucleotides encoding a protein of 159 amino acid residues (Fig. 1A). The predicted
A

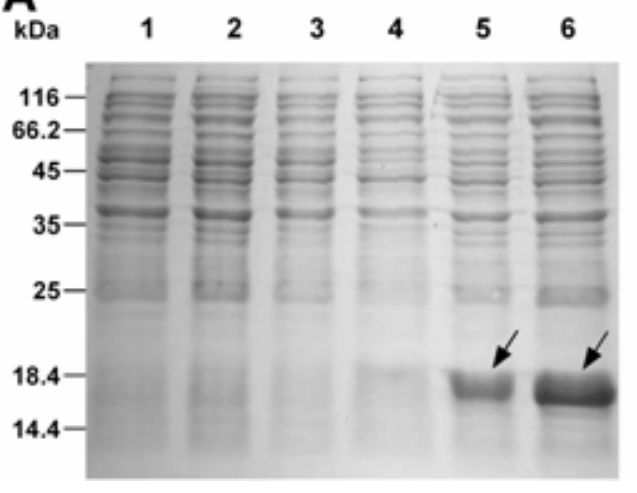

B

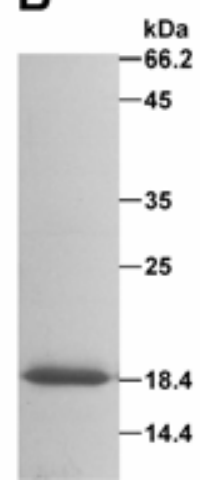

Fig. 2. Sodium dodecyl sulfate polyacrylamide gel electrophoresis analysis of Theobroma cacao pathogenesis-related (PR) protein 10 (TcPR-10) production in bacteria. A, Expression of recombinant TcPR-10 (with HisTag tail) in Escherichia coli BL21(DE3). Lane 1: pET28a without insert and without induction; lane 2: pET28a without insert $3 \mathrm{~h}$ after induction; lane 3: pET28a-TcPR-10 without induction; lane 4: pET28a-TcPR-10 $1 \mathrm{~h}$ after induction; lane 5: pET28a-TcPR-10 $2 \mathrm{~h}$ after induction; lane 6: pET28a-TcPR-10 $3 \mathrm{~h}$ after induction. Arrows indicate the TcPR-10 protein band. B, Purified recombinant TcPR-10 (18.4 kDa). protein has a calculated isoelectric point of 5.57 and calculated molecular masses of 19.65 and $17.6 \mathrm{kDa}$ with and without the His-Tag, respectively. There is no predicted hydrophobic Nterminal region in the protein sequence. Deduced amino acid sequence of TcPR-10 shows the presence of a conserved $P$ loop motif GXGGXGXXK and a Bev1 domain (Fig. 1A). Four putative phosphorylation sites were detected: three on serine residues $\left(S_{38}, S_{100}\right.$, and $\left.S_{118}\right)$ and one on tyrosine residue $Y_{67}$. The predicted amino acid sequence was aligned with different members of the PR-10 family using ClustalW and was shown to have high homology of conserved amino acids involved in ribonuclease activity ( $\mathrm{P}$ loop domain and $\mathrm{E}_{97}, \mathrm{E}_{149}$, and $\mathrm{Y}_{151}$ residues) (Fig. 1B).

\section{Analysis of expressed recombinant TcPR-10 protein.}

The TcPR-10 gene was cloned in pET28a plasmid and was successfully expressed in Escherichia coli BL21(DE3) after 2 $\mathrm{h}$ of induction (Fig. 2A, lane 5). The highest yield of recombinant protein was obtained after $3 \mathrm{~h}$ of induction (Fig. 2A, lane 6 ) while no visible band was observed in the corresponding control (pET28a without insert) (Fig. 2A, lane 2). The protein had a molecular mass of $18.4 \mathrm{kDa}$, close to the predicted one (19.65 kDa with His-Tag). TcPR-10 was successfully purified with a Talon resin metal-affinity column (Fig. 2B).

\section{TcPR-10 ribonuclease activity.}

In vitro ribonuclease activity of the recombinant TcPR-10 is shown in Figure 3A. TcPR-10 $(1 \mu \mathrm{g})$ was capable of degrading $M$. perniciosa RNA $(1 \mu \mathrm{g})$ in a time-dependent manner. High molecular weight RNA smears were observed after 2, 4, and 8 min of incubation (Fig. 3, lanes 2 to 4 ) while short molecular
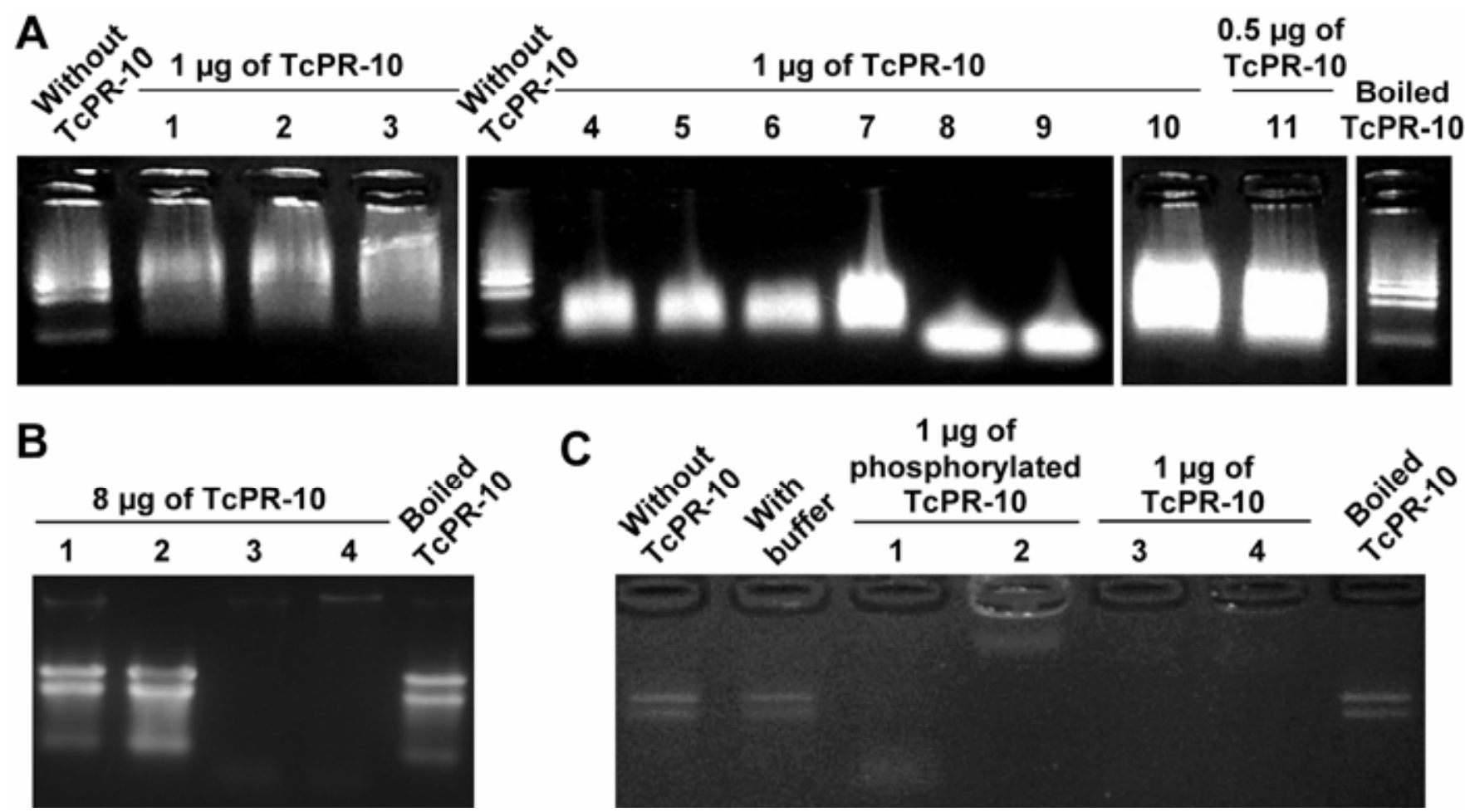

Fig. 3. Ribonuclease activity of recombinant Theobroma cacao pathogenesis-related (PR) protein 10 (TcPR-10). A, Ribonuclease activity in vitro on Moniliophthora perniciosa RNA. TcPR-10 (1 or $0.5 \mu \mathrm{g}$ ) was incubated for various times with $1 \mu \mathrm{g}$ of $M$. perniciosa RNA at $25^{\circ} \mathrm{C}$. Incubation time: lane 1,2 $\mathrm{min}$; lane 2, $4 \mathrm{~min}$; lane 3, $8 \mathrm{~min}$; lane 4, $15 \mathrm{~min}$; lane 5, $30 \mathrm{~min}$; lane 6, $1 \mathrm{~h}$; lane 7, $2 \mathrm{~h}$; lane 8, $4 \mathrm{~h}$; lane 9, $6 \mathrm{~h}$; lane 10, $16 \mathrm{~min}$; and lane 11, $32 \mathrm{~min}$. RNA was also incubated $6 \mathrm{~h}$ without TcPR-10 and with $1 \mu \mathrm{g}$ of boiled TcPR-10. B, Ribonuclease activity in vivo on M. perniciosa. TcPR-10 (8 $\mu \mathrm{g})$ was incubated with $M$. perniciosa broken hyphae at $25^{\circ} \mathrm{C}$ for varying incubation times. Then, fungal RNA was extracted and analyzed by RNase-free agarose gel electrophoresis. Incubation times: lane 1, $15 \mathrm{~min}$; lane 2, $30 \mathrm{~min}$; lane 3, $1 \mathrm{~h}$; and lane 4, $24 \mathrm{~h}$. Broken hyphae were also incubated $24 \mathrm{~h}$ without TcPR-10 and with $8 \mu \mathrm{g}$ of boiled TcPR-10. C, Ribonuclease activity in vitro on cacao RNA. Phosphorylated (lanes 1 and 2) or nonphosphorylated (lanes 3 and 4) TcPR-10 $(1 \mu \mathrm{g})$ was incubated with cacao RNA at $25^{\circ} \mathrm{C}$ for varying incubation times: lanes 1 and $3,1 \mathrm{~h}$; and lanes 2 and $4,6 \mathrm{~h}$. Cacao RNA was also incubated for 24 $\mathrm{h}$ without TcPR-10, only with buffer, and with $1 \mu \mathrm{g}$ of boiled TcPR-10. 
weight RNAs were observed after longer incubation times (from $15 \mathrm{~min}$ to $6 \mathrm{~h}$ ) (Fig. 3, lanes 6 to 11). Control RNA, either untreated with TcPR-10 or incubated with $1 \mu \mathrm{g}$ of boiled TcPR-10, showed no degradation (Fig. 3, lanes 1 and 5). Degradation was exposure concentration dependent because half the amount of protein needed double of the time to achieve the same RNA degradation (Fig. 3, lanes 12 and 13).

In vivo ribonuclease activity of TcPR-10 was also observed (Fig. 3B); broken hyphae were incubated with $8 \mu \mathrm{g}$ of TcPR10 , washed with diethylpyrocarbonate (DEPC) water, and then used for RNA extraction. A complete degradation of $M$. perniciosa RNA was observed after 1 and $24 \mathrm{~h}$ of incubation (Fig. 3B, lanes 3 and 4) while shorter incubation times (15 and 30 min) (Fig. 3B, lanes 1 and 2) yielded only limited RNA degradation. A control sample corresponding to broken hyphae incubated $24 \mathrm{~h}$ with $8 \mu \mathrm{g}$ of boiled TcPR-10 showed no degradation (Fig. 3B).

In vitro ribonuclease activity on cacao RNA was also tested (Fig. 3C). Because phosphorylation of PR-10 may influence substrate specificity (self RNA versus nonself RNA) (Park et al. 2004), we first phosphorylated TcPR-10 and tested its activity on cacao RNA. Both phosphorylated and nonphosphorylated TcPR-10 degraded plant RNA (after 1 or $6 \mathrm{~h}$ of incubation) Fig. $3 \mathrm{C}$, lanes 1 to 4 ) whereas a control sample corresponding to cacao RNA incubated for $24 \mathrm{~h}$ with $1 \mu \mathrm{g}$ of boiled TcPR-10 or with buffer showed no degradation (Fig. 3C).

\section{Antifungal activity, internalization}

of TcPR-10, and membrane permeability in M. perniciosa.

To test the antifungal activity of TcPR-10 on $M$. pernici$o s a$, increasing concentrations of the recombinant protein (chronic exposure, from 0 to $8 \mu \mathrm{g} /$ plate) were incubated either with mono- or dikaryotic broken hyphae of $M$. perniciosa or with basidiospores (Fig. 4). Dikaryotic cultures were the most sensitive to TcPR-10 (3\% survival of CFU) whereas monokaryotic cultures and basidiospores showed the same high resistance to TcPR-10 (20\% of survival) (Fig. 4). Morphology of $M$. perniciosa colonies was the same regardless of TcPR-10 exposure concentration or treatment with boiled TcPR-10 (Fig. 4, inset).

Sensitivity of $M$. perniciosa cells to TcPR-10 was associated with internalization of the protein in a time-dependent manner (from $30 \mathrm{~min}$ to $6 \mathrm{~h}$ ). Fluorescein isothiocyanate (FITC)TcPR-10 was observed throughout the $M$. perniciosa hyphae. However, a more intense green fluorescence was observed in some foci (Fig. 5B, FITC, arrows), which were colocalized with an increase of membrane permeability visualized by propidium iodide (PI) red fluorescence (Fig. 5B, PI, arrows). Uptake of TcPR-10 was inhibited by $0.05 \%$ of $\mathrm{NaN}_{3}$ and by low incubation temperature $\left(4^{\circ} \mathrm{C}\right.$ ) (Fig. 5D and $\mathrm{E}$, respectively). Boiled TcPR-10 labeled with FITC neither showed fluorescence nor increased membrane permeability (Fig. 5F).

\section{Antifungal activity, internalization \\ of TcPR-10, and membrane permeability in $S$. cerevisiae.}

Twenty-nine mutant strains $S$. cerevisiae with defects in different metabolic pathways were used to define probable TcPR10 mechanisms of action using a semi-quantitative drop-test for screening (Table 1) (Pungartnik et al. 2002). In these experimental conditions, among the 29 yeast null mutants pertaining to different metabolic pathways tested for sensitivity to TcPR-10 in chronic exposure, none was more sensitive than the isogenic wild type (WT) and only 2 (defect in high-affinity copper transport) showed a hyper-resistance phenotype (Table 1). It should be noted that four different WT strains were used and the mutants' phenotypes were compared with that of their

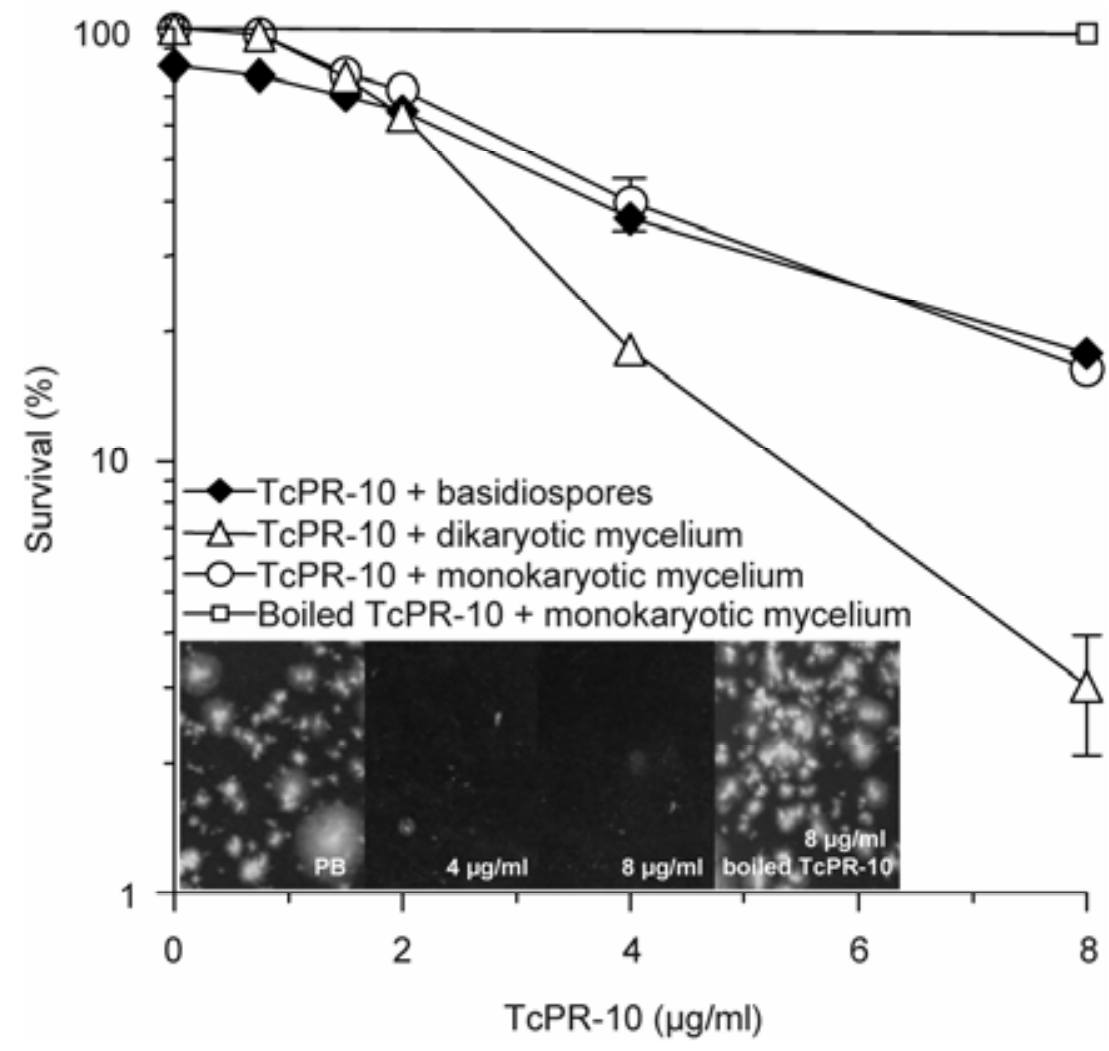

Fig. 4. Effect of Theobroma cacao pathogenesis-related (PR) protein 10 (TcPR-10) on Moniliophthora perniciosa growth and germination. Survival of M. perniciosa monokaryotic and dikaryotic broken hyphae and basidiospores incubated with different TcPR-10 concentrations. The inset shows morphology of $M$. perniciosa monokaryotic pseudocolonies after TcPR-10 exposure (4 and $8 \mu \mathrm{g} / \mathrm{ml}$ ) and control conditions (exposure to phosphate buffer and boiled TcPR-10 at $8 \mu \mathrm{g} / \mathrm{ml})$. 


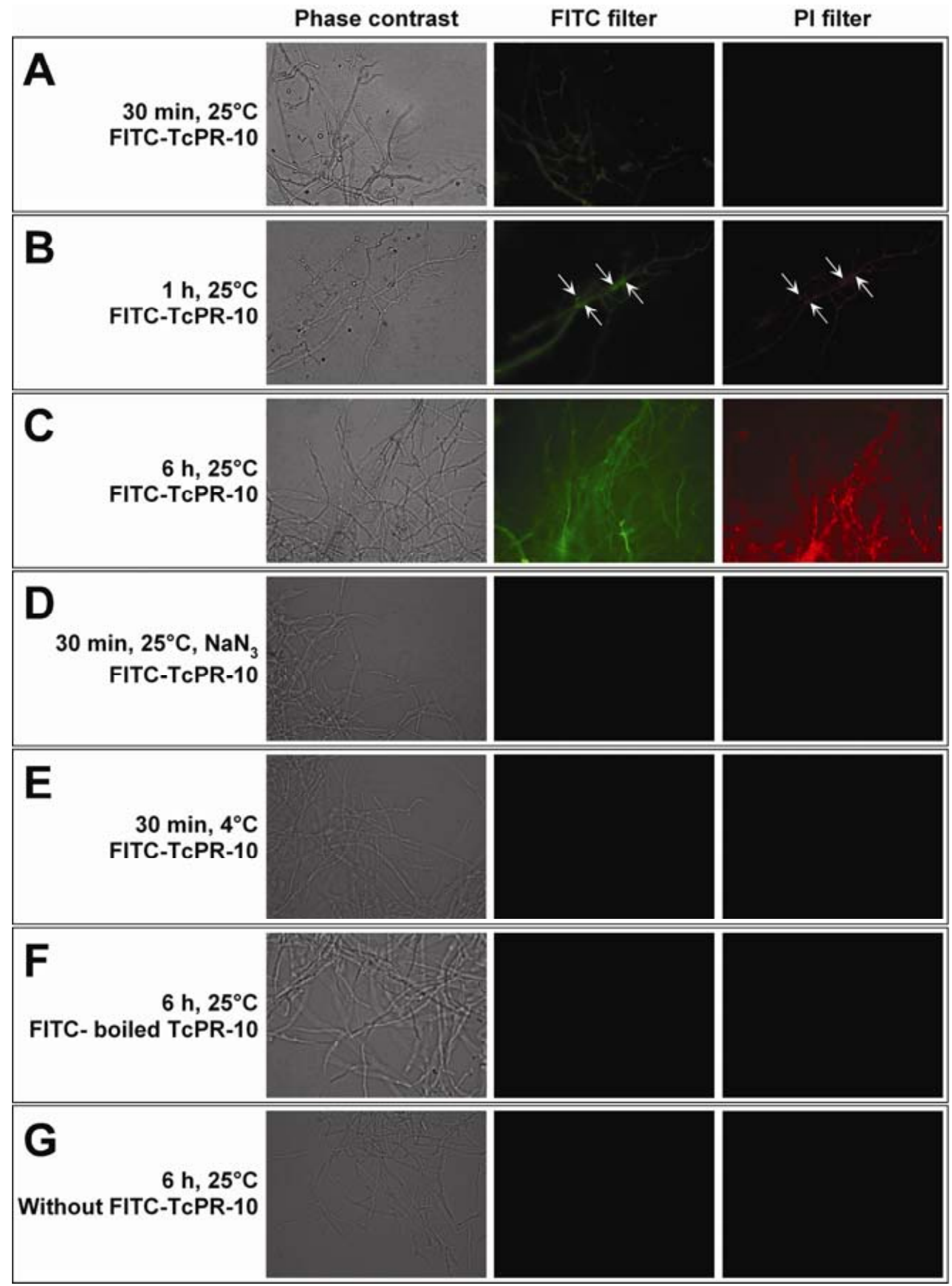

Fig. 5. Internalization of fluorescein isothiocyanate (FITC)-Theobroma cacao pathogenesis-related (PR) protein 10 (TcPR-10) and membrane permeability of Moniliophthora perniciosa hyphae. FITC-TcPR-10 was incubated with M. perniciosa hyphae at $25^{\circ} \mathrm{C}$ with or without $\mathrm{NaN}_{3}$, and membrane integrity was checked by using propidium iodide (PI) uptake assay. Hyphae were observed under fluorescence microscope at different exposure times ( $30 \mathrm{~min}$ to $6 \mathrm{~h}$ ) and images were taken under phase contrast, FITC filter, and PI filter. 
respective $\mathrm{WT}$, and that $\mathrm{TcPR}-10$ had higher toxicity in the copper transporter group (Table 1).

Using a more precise experimental approach, chronic exposure to TcPR-10 of cells in stationary (STAT) phase showed that the snq3 2 yap $1 \Delta$ mutant (lacking a transcription factor activated by oxidative stress) was slightly more sensitive $(P<$ 0.05 , unpaired $t$ test, one-tail and two-tail) than the corresponding WT, while another 4-nitroquinoline- $N$-oxide (4NQO)-sensitive mutant, snql $\Delta / a t r l \Delta$, had WT-like resistance at TcPR-10 exposure doses from 6 to $15 \mu \mathrm{g} /$ plate (Fig. 6A). Because Yap1 protein is known to be activated by oxidative stress (Miyahara et al. 1996), two oxidative stress-sensitive mutants, sod $2 \Delta$ and $\operatorname{cta} 1 \Delta$, were also analyzed (Fig. 6B). These two mutants had WT-like resistance at all tested doses (Fig. $6 \mathrm{~B})$. Because expression of export permease Snq2 protein is controlled by Yap1, we included the snq2 $\Delta$ mutant in our tests and found it to have WT-like resistance to Tc-PR10. Boiled TcPR-10 at the highest dose $(15 \mu \mathrm{g} /$ plate $)$ showed no killing at all in any of the mutant strains (data not shown).

Yeast STAT cells exposed to FITC fluorescent-labeled TcPR-10 did not take up significant amount of the protein during $24 \mathrm{~h}$ of exposure (data not shown). Therefore, we analyzed the time course of TcPR-10 internalization in yeast exponen- tially growing (LOG) cells (Figs. 7 and 8). We first assessed TcPR-10 sensitivity under these LOG conditions: LOG cells of ABC transporter mutant snq2 $\Delta$ were more resistant than LOG cells of the isogenic WT with TcPR-10 exposure at $3 \mu \mathrm{g} / \mathrm{ml}$ during $6 \mathrm{~h}$ (Fig. 7A). Because ABC transporters are Yap1 transcription activator inducible, we exposed snql Vatrl $\Delta$ (resistant to aminotriazole) and snq3 $\Delta$ yap $1 \Delta$ mutants to the same doses as before. Interestingly, neither of the two showed statistical difference in survival when compared with the respective isogenic WT (Fig. 7B).

In order to find out whether sensitivity to TcPR-10 is directly correlated with cellular uptake of protein (internalization), we followed protein accumulation with FITC-labeled TcPR-10 in LOG phase cells and checked for viability with PI (Fig. 8). In the WT BY10000, TcPR-10 accumulated (from 15 to $60 \mathrm{~min}$ of exposure) whereas there was no increase in internalization of TcPR-10 in the isogenic snq2 $\Delta$ mutant. The same pattern was seen in the viability test with PI after TcPR-10 exposure: in the WT, the number of nonviable cells increased with exposure time, whereas this was not so for mutant snq2A (Fig. 8A and B), confirming its higher resistance to TcPR-10 (Fig. 7A). Interestingly, the high-affinity copper transporter mutants treated with the same amount of labeled TcPR-10 had the same uptake

Table 1. Saccharomyces cerevisiae strains used in this study, their relevant protein function, and their response to Theobroma cacao pathogenesis-related protein 10 (TcPR-10) incubation

\begin{tabular}{|c|c|c|c|c|}
\hline Yeast mutant strains ${ }^{\mathrm{a}}$ & Protein function & Response $^{\mathrm{b}}$ & Phenotype $^{c}$ & Source \\
\hline BY10000 & Wild type & - & & EUROSCARF \\
\hline $\begin{array}{l}\operatorname{rad} 1 \Delta, \operatorname{rad} 30 \Delta, \operatorname{rad} 14 \Delta, p s o 2 \Delta, \\
\operatorname{rnr} 4 \Delta\end{array}$ & DNA repair metabolism & $\mathrm{ND} / \mathrm{WT} *$ & & \\
\hline $\operatorname{sod} 2 \Delta, \operatorname{cta} 1 \Delta$ & Anti-oxidant defenses & ND/WT* & & \\
\hline 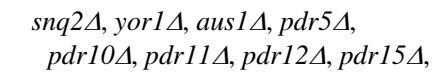 & Membrane transport & ND/WT* & & \\
\hline YPH98 & Wild type & - & & P. Hieter \\
\hline snq1 VatrlA & Membrane transport & ND/WT* & & M. Brendel \\
\hline $\operatorname{snq} 3 \Delta$ yap $1 \Delta$ & Anti-oxidant defenses & $\mathrm{ND} / \mathrm{WT}^{* \mathrm{~d}}$ & & \\
\hline DTY401 & Wild-type & - & & D. J. Thiele \\
\hline fre $1 \Delta$, fre $2 \Delta$ & Ferric and cupric reductase & ND/WT* & & \\
\hline DY1457 & Wild-type & - & & D. J. Eide \\
\hline$z r t 1 \Delta, z r t 2 \Delta, z a p 1 \Delta$ & Zinc transporter & $\mathrm{ND} / \mathrm{WT} *$ & & \\
\hline fet $3 \Delta$, fet $4 \Delta$, aft $1 \Delta$ & Ferrous transporter & ND/WT* & & \\
\hline DTY165 & Wild-type & - & & D. J. Thiele \\
\hline $\operatorname{ctrl} 1 \Delta$ & $\begin{array}{l}\text { High-affinity copper transporter of the } \\
\text { plasma membrane }\end{array}$ & HypR** & & \\
\hline $\operatorname{ctr} 2 \Delta$ & $\begin{array}{l}\text { Putative low-affinity copper transporter of } \\
\text { the vacuolar membrane }\end{array}$ & HypR** & & \\
\hline $\operatorname{ctr} 3 \Delta$ & $\begin{array}{l}\text { High-affinity copper transporter of the } \\
\text { plasma membrane }\end{array}$ & HypR** & & \\
\hline $\operatorname{macl\Delta }$ & $\begin{array}{l}\text { Copper-sensing transcription factor involved } \\
\text { in regulation of genes required for high- } \\
\text { affinity copper transport }\end{array}$ & HypR** & & \\
\hline
\end{tabular}

\footnotetext{
${ }^{a}$ Haploid cells. compared with the isogenic WT.

${ }^{\mathrm{c}}$ One strain representative of the whole series was tested.

${ }^{\mathrm{d}} \mathrm{ND} / \mathrm{WT}$ on drop test but sensitive on refine analysis.
}

${ }^{\mathrm{b}}$ Response to TcPR10 on drop test. ND/WT $=$ not different from isogenic wild type; $*$ and $* *=8$ and $5 \mu \mathrm{g} / \mathrm{plate}$, respectively; and HypR $=$ hyper-resistant 
kinetics as the respective WT (Fig. 8C, D, and E), although the mutants were hyperresistant to the protein (Table 1).

\section{DISCUSSION}

In this article, we reported the characterization of a PR-10 cDNA from cacao and its corresponding protein, designated as TcPR-10. The TcPR-10 ORF was 480 bp in length and encoded a polypeptide of 159 amino acids with a molecular mass of $18.4 \mathrm{kDa}$, which is in accordance with the general characteristics of the PR-10 family: i) ORF from 456 to $489 \mathrm{bp}$, ii) protein from 151 to 162 amino acids, and iii) protein molecular mass of 15 to $19 \mathrm{kDa}$ (Liu and Ekramoddoullah 2006). TcPR-10 shares high amino acid sequence similarity with different typical members of the ubiquitous family of PR-10 such as PR-1 from Fagus sylvatica and Betv1 from Vitis vinifera (Fig. 1B). Sequence analysis revealed that TcPR-10 contains no signal peptide, suggesting that it is an intracellular protein located in the cytosol in contrast to most other PR proteins, which are generally extracellular (Ziadi et al. 2001). This result also suggests that TcPR-10 belongs to the IPR group, which is known to have homology with ribonucleases (van Loon et al. 1994). The presence of a $\mathrm{P}$ loop motif (GXGGXGXXK) and conserved amino acids such as $\mathrm{E}_{97}, \mathrm{E}_{149}$, and $\mathrm{Y}_{151}$, considered to be involved in the ribonuclease activity (Bantignies et al. 2000; Chadha and Das 2006), indicated the possible RNase activity of TcPR-10. Putative phosphorylation sites, correlated to RNase activity levels in other proteins (Liu et al. 2006), were also encountered in the TcPR-10 sequence $\left(\mathrm{S}_{38}, \mathrm{~S}_{100}, \mathrm{~S}_{118}\right.$, and $\left.\mathrm{Y}_{67}\right)$. The expression of active recombinant TcPR-10 protein in a bacterial system is supported by the absence of putative $\mathrm{N}$-glycosylation sites (A-X-S/T type) (Lerouge et Faye 1996) in the amino acid sequence (Fig. 1A).

Purified recombinant TcPR-10 indeed showed RNase (and no DNAse) (data not shown) activity on $M$. perniciosa RNA (Fig. 3) as predicted by its amino acid sequence, and also had antifungal toxicity (Figs. 4 and 6). The correlation of in vitro RNase activity with antimicrobial activity of PR-10 proteins
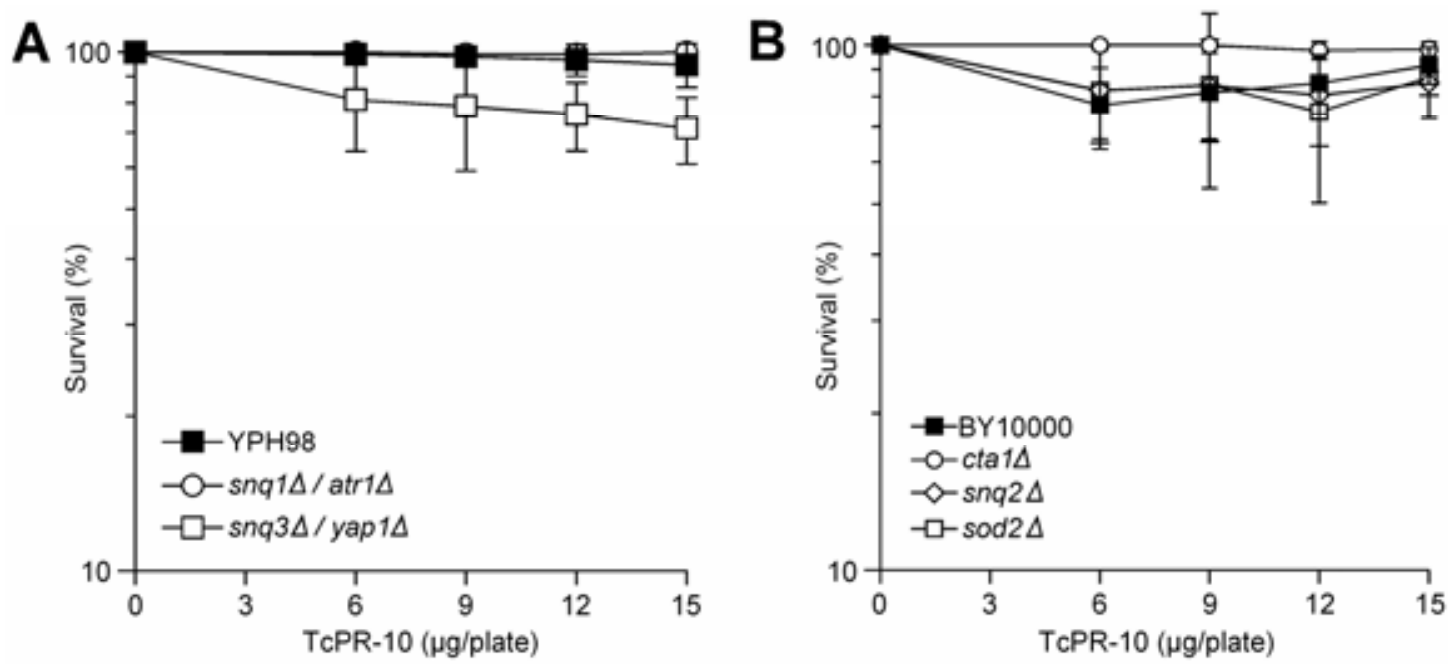

Fig. 6. Effect of chronic exposure of Saccharomyces cerevisiae to Theobroma cacao pathogenesis-related (PR) protein 10 (TcPR-10). A, Survival of wildtype (WT) YPH98 and derived mutant strains snq3 Nyap1 $\Delta$ and snq1 Natr1 $\Delta$. Stationary (STAT) phase cells were grown in the presence of different TcPR-10 concentrations. B, Survival of WT BY10000 and derived mutant snq2A, sod2A, and ctal $\Delta$. STAT phase cells were grown in the presence of different TcPR10 concentrations.
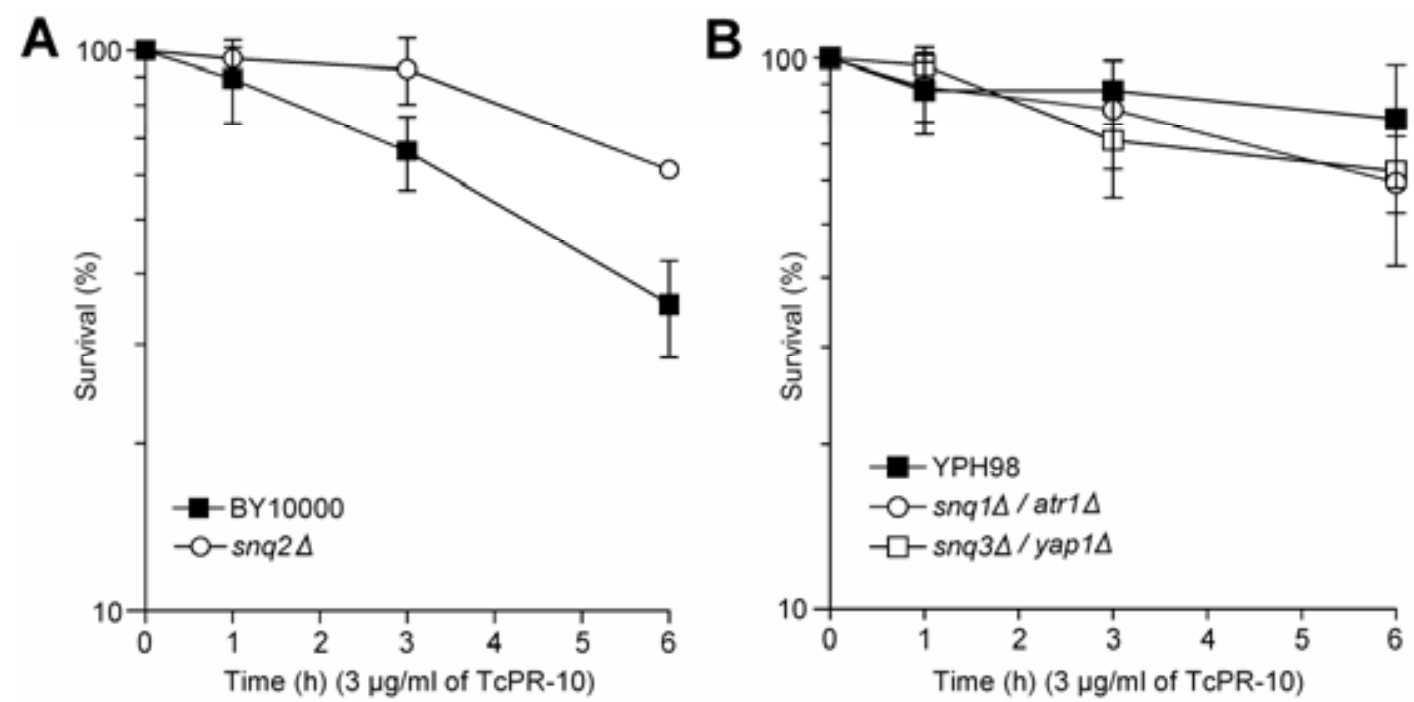

Fig. 7. Kinetics of toxicity of Theobroma cacao pathogenesis-related (PR) protein 10 (TcPR-10) on Saccharomyces cerevisiae exponentially growing cells. A, Exposure time-dependent survival of BY10000 and derived mutant snq2 $\Delta$ incubated with TcPR-10 at $3 \mu \mathrm{g} / \mathrm{ml}$ for 0 , 3, and $6 \mathrm{~h}$. B, Exposure timedependent survival of YPH98 and derived mutants snq3 Vyap1 $\Delta$ and snq1 Vatr1 $\Delta$ incubated with TcPR-10 at $3 \mu \mathrm{g} / \mathrm{ml} \mathrm{for} 0,3$, and $6 \mathrm{~h}$. 
was already shown. CaPR-10 protein from hot pepper (Capsicum annuum) inhibited growth of the oomycete pathogen $P$. capsici and also exhibited ribonuclease activity against $T o$ bacco mosaic virus RNA (Park et al. 2004); SsPR-10 from So- lanum surattense and the AhPR-10 from Arachis hypogaea L. (peanut) showed both ribonuclease and antimicrobial activity (Chadha and Das 2006; Liu et al. 2006). In the case of Betv1 from birch (Betula verrucosa) pollen (Bufe et al. 1996;
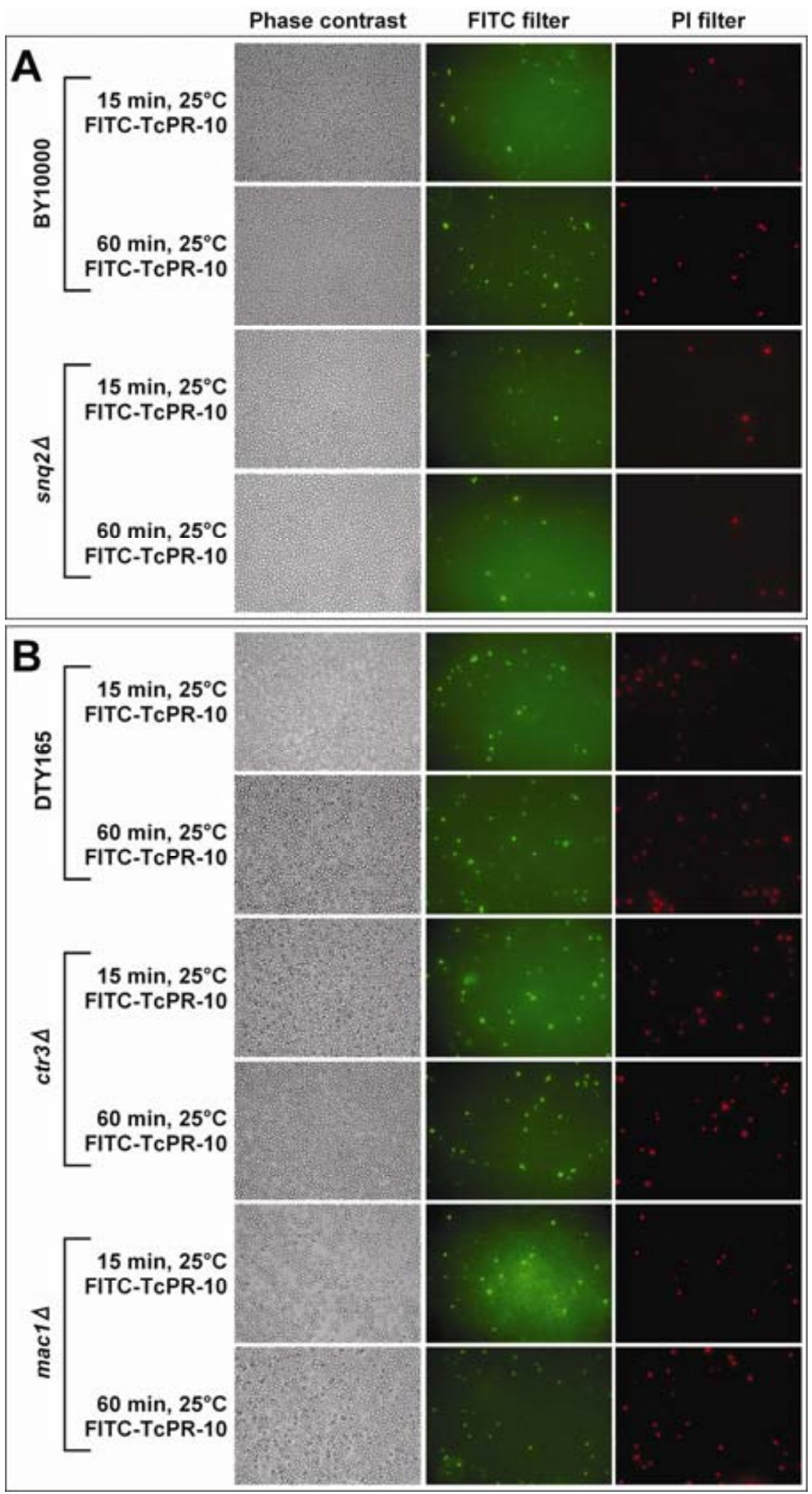

Fig. 8. Internalization of fluorescein isothiocyanate (FITC)-Theobroma cacao pathogenesis-related (PR) protein 10 (TcPR-10) by Saccharomyces cerevisiae exponentially growing cells. A, Wild-type (WT) BY10000 and mutant strain snq2A incubated with FITC-TcPR-10 and propidium iodide (PI) at $25^{\circ} \mathrm{C}$. B, DTY 165 and isogenic mutants ctr3 $\Delta$ and macl $\Delta$ incubated with FITC-TcPR-10 and PI at $25^{\circ} \mathrm{C}$. Cells were observed under fluorescence microscope at different time points (15 and $60 \mathrm{~min}$ ) and images were taken under phase contrast and FITC and PI filters. 
Swoboda et al. 1996), LaPR-10 from lupine (Lupinus albus) roots (Bantignies et al. 2000), and GaPR-10 from Gossypium arboretum (Zhou et al. 2002), only the ribonuclease activity was demonstrated.

The in vitro ribonuclease activity of some PR-10 proteins to plant defense responses may possibly be explained by the fact that their RNase activity may either help to protect plants during programmed cell death (PCD) around infection sites (hypersensitive response [HR]) or may act directly on the pathogen (Liu and Ekramoddoullah 2006). With regard to witches' broom disease, the TcPR-10 gene was obtained from the compatible cacao- $M$. perniciosa cDNA interaction which is known to involve PCD in the final stage of the disease (Ceita et al. 2007; Garcia et al. 2007). During the PCD process, the plasma membrane breaks and the cell content is released to the apoplast while $M$. perniciosa invades the plant cells (changes from inter- to intracellular mycelium growth) (Ceita et al. 2007). In these conditions, TcPR-10 may be involved in acting directly on the pathogen as an ultimate attempt to impede fungal development. On an other hand, the pathogen-triggered PCD that leads to the death of the infected cacao tissues seems important for the fungus to change its phase from biotrophic to saprotrophic (necrotrophic) in vivo (Ceita et al. 2007). As a consequence of the pathogen's strategy, the TcPR-10 RNase activity may participate in PCD, degrading plant RNA, thus allowing necrosis and death and thereby supporting fungal phase transition and basidiocarp production. This may be supported by the TcPR-10 (phosphorylated or not) RNase activity against plant RNA (Fig. 3C). According to Park and associates (2004), phosphorylation of PR-10 may be related to specificity for certain RNA substrates (fungus self RNA versus nonself RNA). In our conditions, the phosphorylation did not influence the RNase activity of TcPR-10 or its substrate specificity (i.e., it degraded both plant and fungus RNA). The biological importance of the RNase activity of TcPR-10 and, more generally, of the other PR-10 proteins with in vitro RNase activity needs to be further investigated. Here, we demonstrated that TcPR-10, when incubated with M. perniciosa hyphae, was also capable of degrading the fungal RNA, thus demonstrating the in vivo activity of the recombinant protein (Fig. 3B).

TcPR-10 showed antifungal activity on both $M$. perniciosa and $S$. cerevisiae. It inhibited $M$. perniciosa mycelial growth as well as basidiospore germination (Fig. 4). Cells from the monokaryotic mycelium and basidiospores had the same sensitivity and were more resistant to TcPR-10 than the dikaryotic mycelium (Fig. 4). An increased sensitivity of dikaryotic cultures against different mutagens has already been shown (Filho et al. 2006) and is correlated with differential expression of genes providing antioxidative defenses in mono- and dikaryotic fungus, and also depends on the medium carbon source (Santos et al. 2008). Also, we may speculate that basidiospores, having the first contact with the putative host and its defenses against pathogens, might be better protected to guarantee a successful infection. This might also be hypothesized for the monokaryotic mycelium evolving from the basidiospore because it may have to endure the initial bursts of defense reactions of a healthy host (Ceita et al. 2007; Garcia et al. 2007; Scarpari et al. 2005).

Our experiments also suggested that the antifungal activity of TcPR-10 may be correlated to its RNase activity as previously suggested by other work (Chadha and Das 2006). Using the AhPR-10K54N mutant protein in internalization experiments, these authors showed that the RNase activity domain was distinct to the site that interacts with the fungal membrane. Denaturation of TcPR-10 led to lack of RNAse activity (Fig. 4), loss of antifungal activity (Fig. 5), and inability to be taken up by both cell types (basidiomycete mycelium or ascomycete single cell) (Fig. 7). According to Morgensen and associates (2002), Betv1 contains two ligand binding sites (one hydrophobic, binding to 8-anilo-1-naphthalenesulfunic acid, and the other binding to kinetin), and the authors suggested that the lys54 adjacent to the P loop in AhPR-10 may interact with the RNA whereas the hydrophobic ligand binding site may interact with the receptor or target site on the fungal membrane (Chadha and Das 2006). The use of PI, known to be a marker of cell viability which enters only through damaged cell membranes, allowed correlating TcPR-10 penetration and antifungal activity to cell viability. However, the uptake of PI after the internalization of TcPR-10 (FITC and PI labeling appeared at $30 \mathrm{~min}$ and $1 \mathrm{~h}$, respectively) (Fig. 5A and B) suggested that the membrane disruption was a consequence of the TcPR-10 introduction within the fungal hyphae, and that TcPR-10 did not act by directly permeabilizing or disrupting the fungal membrane as observed for other antifungal plant proteins (Thevissen et al. 1999). It is interesting to note that the in vivo ribonuclease activity of TcPR-10 (Fig. 3B) initiated $1 \mathrm{~h}$ after incubation, which corresponded to the fist observation of the membrane permeability (Fig. 5B, PI filter) but appeared after the observation of TcPR-10 internalization (Fig. 5A., FITC filter). Accordingly, the temperature dependence of internalization and the $\mathrm{NaN}_{3}$ inhibition, and the fact that yeast STAT cells do not internalize TcPR-10, suggest that it is actively transported into the $M$. perniciosa hyphae or yeast cells, as has been shown for AhPR-10 in other fungi (Chadha and Das 2006).

As a first approach, the chronic exposure to TcPR-10 analyzed by drop test did not render any of 29 yeast mutant cells more sensitive when compared with their isogenic WT (Table 1 ). The drop test is very good for screening larger number of different strains but only shows highly significant differences in sensitivity; each drop represents a decade of survival or killing, because the factor of dilution is 10 between two drops (Pungartnik et al. 2002). A more refined test that reveals smaller differences in sensitivity necessitates establishing a survival curve (Brendel and Haynes 1973). The mutant snq3/yapl, that is generally stress sensitive because it lacks a transcription factor that responds to stress (He and Fassler 2005; Rodrigues-Pousada et al. 2004), was not found sensitive to TcPR-10 in the drop test (less than a decade difference), whereas the inactivation curve revealed a small but significant difference in sensitivity to its isogenic WT (Fig. 6A). Because Yap1/Snq3 protein is known to control, among others, Snq1 and Snq2 permeases (Gounalaki and Thireos 1994) and also the main oxidative stress defense enzymes (catalase and superoxide dismutase), mutants lacking these enzymes were candidates for altered sensitivity to TcPR-10. None were more sensitive than the isogenic WT in STAT phase (Fig. 6A and B).

Surprisingly, copper homeostasis seems to be important, because copper uptake mutant $\operatorname{ctr} 3 \Delta$ and mutant macl $1 \Delta$, lacking its transcription activator factor, displayed higher resistance compared with WT (Table 1). The two mutants showed approximately the same protein internalization (Fig. 8D and E) as their isogenic WT; therefore, we must assume that TcPR-10 enters the mutant cells with WT-like kinetics. Thus, it may not be the lack of TcPR-10 uptake but rather the lack of copper that make the two mutants more resistant. We may speculate that either copper is needed for the toxic action of TcPR-10 (increasing RNAse activity) or the lack of copper leads to an altered metal homeostasis which may be important for modulating toxicity of this protein.

In a more sensitive approach, yeast LOG cells with their highly active membrane transport may be used to measure TcPR-10 toxicity (Fig. 7) and internalization (Fig. 8). The three mutants snq1 $\Delta$, snq2 $\Delta$, and snq3 $\Delta$ were tested for TcPR-10 sensitivity and none was found to be sensitive (Fig. 7B) but the 
snq2 4 mutant was found to be more resistant than the WT (Fig. 7A). Absence of the export permease function of Snq2 protein apparently fails to export a cellular component that, present in higher than normal amount in the cell, inhibits toxicity of TcPR-10. Alternatively, lack of the permease function may inhibit or negatively interfere with internalization of TcPR-10. Surprisingly, the latter seems to occur as shown in Figure $8 \mathrm{~A}$ and $\mathrm{B}$, where uptake of TcPR-10 does not increase between 15 and $60 \mathrm{~min}$ of exposure (Fig. 8B), contrary to the increased uptake in the WT, that shows a higher amount of internal protein at 60 min (Fig. 8A). Perhaps, lack of Snq2 leads to an already observed effect, a compensatory upregulation via Pdr1 of other export permeases (Kolaczkowska et al. 2008), one of them active in exporting TcPR-10.

Although Yap1, a member of the AP-1 family of transcription factors, activates the transcription of antioxidant genes such as SOD2 and CTA1 in response to oxidative stress, this has no apparent influence on sensitivity to TcPr-10. Loss of activity of superoxide dismutase and peroxisomal catalase in yeast mutants $\operatorname{sod} 2 \Delta$ and $\operatorname{cta} 1 \Delta$ does not lead to a TcPr-10-sensitivity phenotype (Fig. 6B). Yap1 is also implicated in multidrug response (Coleman et al. 1997; Gounalaki and Thireos 1994) and, although we did not find any ortholog of YAPl in M. perniciosa, several orthologs (homologs) of yeast Yap1inducible ABC transporters in $M$. perniciosa, including putative $S N Q 2, Y O R 1$, and PDR5 orthologs, were found (Santos et al. 2008).

To our knowledge, this is the first report of heterologous expression of PR-10 from cacao with ribonuclease and antifungal activity against $M$. perniciosa and $S$. cerevisiae. One might consider the possible use of the $T c P R-10$ gene to increase the resistance of $T$. cacao to $M$. perniciosa, similar to the introduction of a class I chitinase gene (Maximova et al. 2006). Our data also suggest that TcPR-10 is actively transported into yeast LOG cells and that its antifungal activity is lower in yeast mutants with impaired high-affinity copper transport and in the absence of Snq2 export permease. A similar scenario (i.e., import and export of antifungal proteins via permeases) may also occur in $M$. perniciosa.

\section{MATERIALS AND METHODS}

\section{Identification of cDNA clone and sequence analysis.}

The TcPR-10 cDNA was identified from a cDNA library of susceptible cacao (cv. Catongo) inoculated by $M$. perniciosa (Gesteira et al. 2007). This library was obtained from a pool of meristems harvested through the disease time course (from 24 $\mathrm{h}$ to 90 days after infection by $M$. perniciosa) (Gesteira et al. 2007). ORF analysis of the nucleotide sequence was performed with ORFinder program (Lasergene, Madison, WI, U.S.A.) followed by homology search with BLAST (Altschul et al. 1997) against sequences in the National Center for Biotechnology Information database. ClustalW was used for multiple sequence alignment of amino acid sequence (Thompson et al. 1994). Putative serine, threonine, and tyrosine phosphorylation sites were predicted on the TcPR-10 amino acid sequence using the NetPhos server (Blom et al. 1999).

\section{Expression of recombinant TcPR-10.}

The TcPR-10 sequence was amplified by PCR using the PR-F (5'-GGCGGGATCCATATGGGTGTCACCACATATAC-3') and PR-R (5'-GGCGGTCGACTTAAGCGTAGACATTGGGAT-3') primers, PCR product was cloned into the NdeI and SalI sites of the plasmid pET28a (Novagen), and the resulting in frame fusion plasmid was transformed into E. coli strain BL21(DE3).

Overexpression of the TcPR-10 tagged with six histine residues at the $\mathrm{N}$-terminus was induced by $1 \mathrm{mM}$ isopropyl- $\beta$-D- thiogalactoside at $37^{\circ} \mathrm{C}$. To establish the kinetics of TcPR-10 induction, bacteria were collected and protein content analyzed 1,2 , and $3 \mathrm{~h}$ after induction. Larger quantities of TcPR-10 that are needed for protein purification were obtained after $4 \mathrm{~h}$ of induction. For recombinant protein purification, bacteria were harvested by centrifugation and once, washed in equilibration buffer (50 mM phosphate buffer [PB], $300 \mathrm{mM} \mathrm{NaCl}, \mathrm{pH} 7.4$ ), suspended in lysis buffer (50 mM PB, $300 \mathrm{mM} \mathrm{NaCl}$, lysozyme at $0.1 \mathrm{mg} / \mathrm{plate}, \mathrm{pH} 7.4$ ) and kept at room temperature for $1 \mathrm{~h}$. The sample was then chilled in ice and sonicated (Gex Ultrasonic processor $130,130 \mathrm{~W}$; eight pulses of $30 \mathrm{~s}$ each, $75 \%$ output, $30 \mathrm{~s}$ intervals), and the resulting lysate centrifuged for $20 \mathrm{~min}$ at $11,000 \times g$. The supernatant was collected for purification of soluble protein while the insoluble fraction, contained in the inclusion bodies, was solubilized with $6 \mathrm{M}$ urea. Both soluble and insoluble proteins were loaded onto Talon resin metal affinity column (Clontech Laboratories), eluted with $150 \mathrm{mM}$ imidazole, and dialyzed against $500 \mathrm{ml}$ of 50 $\mathrm{mM}$ PB, pH 7.0 (during 2 days with eight buffer exchanges). Final concentration of proteins was obtained in $50 \mathrm{mM} \mathrm{PB}$, pH7.0.

\section{TcPR-10 SDS-PAGE.}

Sodium dodecyl sulfate polyacrylamide gel electrophoresis (SDS-PAGE) was performed as described by Laemmli (1970) using 5 and $12.5 \%$ polyacrylamide in the stacking and resolving gels, respectively. Briefly, after denaturation at $95^{\circ} \mathrm{C}$ for 3 min, proteins were resolved under constant $150 \mathrm{~V} / 280 \mathrm{~mA} / 60$ $\mathrm{W}$ electrophoresis and proteins were visualized with $5 \%$ (wt/vol) colloidal Coomassie G 250 (Neuhoff et al. 1988). The molecular weight marker was from Fermentas. Concentration of soluble and insoluble proteins was determined by Bradford assay (Biorad) using bovine serum albumin as protein standard (Bradford 1977).

\section{M. perniciosa growth conditions.}

M. perniciosa strain ALF553 cultures were grown and toxicity tests were performed as described by Filho and associates (2006). Dikaryotic cultures were grown in CPD (2\% glucose, $2 \%$ peptone) and monokaryotic cultures in CPG (2\% glycerol, $2 \%$ peptone) in liquid media, without agitation, at $25^{\circ} \mathrm{C}$ for 5 to 7 days. Agar (2\%) was added when solid media were used.

$M$. perniciosa spores were obtained from the fungal collection of Comissão Executiva do Plano da Lavoura Cacaueira. Spore germination was checked by spreading $10^{4}$ spores onto a $2 \%$ agar/water plate, incubating them at $25^{\circ} \mathrm{C}$ for $4 \mathrm{~h}$ and examining the germinating tube formation under a light microscope (Interprise). Samples with more than $90 \%$ spore germination were considered viable and appropriate for experimentation.

\section{S. cerevisiae strains and growth conditions.}

$S$. cerevisiae strains used were constructed elsewhere: YPH98 (MATa ade2-101 lys2-801 ura3-52 trp1-1 leu2-1) (Sikorski and Hieter 1989) and the derived mutant strains

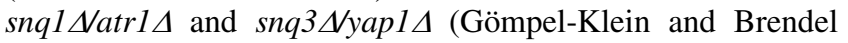
1990; Hertle et al. 1991); isogenic BY10000 (MAT $\alpha$ his3A leu2 $\Delta 0$ lys $2 \Delta O$ ura3 $\Delta O$ ) and derived mutant strains (same genotype as BY10000 except for genes of interest, which were replaced by kanMX4) (from EUROSCARF; Brachmann et al. 1998) isogenic DY1457 (MAT $\alpha$ : ade6 can1-100oc his3 leu2 trpl ura3) and derived mutant strains (same genotype except for genes of interest, fet $3:: H I S 3$, fet $4:: L E U 2$, zrt $1:: L E U 2$, zrt2::HIS3, zapl::TRP1, aft1::TRP1); isogenic DTY165

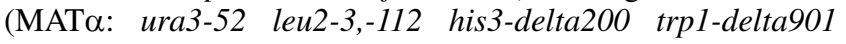
lys2-801 suc2-delta9) and derived mutant strains (same genotype except for genes of interest, ctr $1:: U R A 3$, ctr3::LEU2, ctr2::HIS3); isogenic DTY401 (BY4741) (MATa: his $\Delta 1$ 
leu2 $\Delta O$ met15 $\Delta O$ ura3 $\Delta O$ ) and derived mutant strains (same genotype except for genes of interested fre $1:: H I S 3$ and fre $\left.2: \because K a n^{\mathrm{r}}\right)$.

Strains were grown and stored on YPD media (2\% glucose, $2 \%$ peptone, $1 \%$ yeast extract; $2 \%$ agar added for solid medium) at $30^{\circ} \mathrm{C}, 180 \mathrm{rpm}$, in a gyratory water-bath shaker (G76; New Brunswick Scientific Co., Edison, NJ, U.S.A.) for 2 days (STAT cells). LOG cells were obtained either by inoculation of fresh media with $10^{6}$ STAT cells/ml and grown with shaking for 4 to $5 \mathrm{~h}$ at $30^{\circ} \mathrm{C}$ until 1 to $2 \times 10^{7}$ cells $/ \mathrm{ml}$, or by a colony suspension spread on a YPD plate, incubated overnight (16 to $18 \mathrm{~h}$ ), after which cells were collected, washed three times with $0.9 \% \mathrm{NaCl}$, and resuspended to a final concentration of 2 $\times 10^{7}$ cells $/ \mathrm{ml}$. To ascertain their respiratory competence and for elimination of spontaneously accumulated petites, all strains were pregrown on YPG media (YPD in which glucose replaced by $2 \%$ glycerol) before being grown in liquid YPD. Media, solutions, and buffers were prepared according to Burke and associates (2000).

\section{TcPR-10 phosphorylation.}

Green brooms from cacao were harvested and native protein extract was prepared as described by Pirovani and associates (2008). The supernatant served as the enzyme source for the kinase studies. Native plant protein extract was supplemented

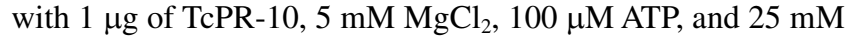
$\mathrm{KCl}$ in a total volume of $40 \mu \mathrm{l}$. The reaction was performed at $30^{\circ} \mathrm{C}$ for $40 \mathrm{~min}$ and terminated with the addition of EDTA to $5 \mathrm{mM}$. Phosphorylation of TcPR-10 was check by protein separation on SDS-PAGE as described above. Then, phosphorylated TcPR-10 was purified onto a Talon resin metal affinity column (Clontech Laboratories) according to the manufacturer's recommendations. Phosphorylated TcPR-10 was used in ribonuclease activity assays on plant RNA.

\section{Ribonuclease activity assay.}

For in vitro ribonuclease activity assay, RNA degradation was assayed according to Bantignies and associates (2000) with modifications. $M$. perniciosa and cacao RNA were extracted with the RNAqueous kit (Ambion). RNA $(1 \mu \mathrm{g})$ in DEPC water was incubated with different concentrations of purified recombinant phosphorylated or nonphosphorylated TcPR-10 $(0.5$ or $1 \mu \mathrm{g})$ at $28^{\circ} \mathrm{C}$ at different times $(2$ min to $4 \mathrm{~h})$. Reaction mixtures were analyzed by $1 \%$ agarose (wt/vol) RNase-free gel electrophoresis with ethidium bromide staining.

For in vivo ribonuclease activity assay, M. perniciosa was grown in CPD for 10 days. Then, $300 \mathrm{mg}$ of broken hyphae obtained as described by Filho and associates (2006) was incubated with nonphosphorylated TcPR-10 at $25^{\circ} \mathrm{C}$ from $15 \mathrm{~min}$ to $24 \mathrm{~h}$ in a final volume of $1 \mathrm{ml}$. After incubation, the broken hyphae were washed with $5 \mathrm{ml}$ of DEPC water. RNA was extracted from washed broken hyphae using the RNAqueous kit (Ambion) and analyzed on 1\% agarose (wt/vol) RNase-free gel electrophoresis with ethidium bromide staining.

\section{Antifungal activity of TcPR-10.}

Against M. perniciosa. TcPR-10 $(0.75,1.5,2,4$, or 8 $\mu \mathrm{g} /$ plate) was spread onto $20 \mathrm{ml}$ of either CPG or CPD agar plates. Each $1 \mathrm{ml}$ of mono- or dikaryotic $M$. perniciosa broken hyphae (Filho et al. 2006) was spread onto three plates of either CPG (control) or CPD + TcPR-10 plates and further incubated for 7 days at $25^{\circ} \mathrm{C}$. Survival was defined as the percentage of grown pseudocolonies (treated/nontreated control $\times$ 100). TcPR-10 cytotoxicity on basidiospores and inhibition of germinating tube formation were assayed at the same concentrations of TcPR-10 per plate; basidiospores were diluted with $\mathrm{PB}$ to obtain a maximum of 200 colonies per plate and incu- bated for 7 days at $25^{\circ} \mathrm{C}$. Spore viability and inhibition of germinating tube formation were assayed as described above. TcPR-10 was boiled for $1 \mathrm{~h}$ at $100^{\circ} \mathrm{C}$ and used as a negative control in the same conditions.

Against S. cerevisiae. i) Chronic exposure: TcPR-10 (1 to 15 $\mu \mathrm{g} / \mathrm{plate}$ ) was spread onto $20 \mathrm{ml}$ of YPD agar plates. Colony forming ability (survival) of yeast STAT cells was assayed by exposing them to different concentrations of TcPR-10 for 3 to 4 days at $30^{\circ} \mathrm{C}$. ii) Acute exposure: yeast LOG cells were exposed to TcPR- $10,25^{\circ} \mathrm{C}$, shaking $3 \mu \mathrm{g} / \mathrm{ml}(0$ to $6 \mathrm{~h}$ in liquid PB); after appropriate dilution, cells were plated on YPD agar and assayed for survival after 2 to 3 days of incubation at $30^{\circ} \mathrm{C}$. The surviving fraction was determined by dividing the number of agar-grown colonies by milliliter of treated or nontreated cells.

Results for antifungal activity of TcPR-10 are the mean of at least three independent experiments. They are presented in a semilog graph (Brendel and Haynes 1973) for rapid estimation of dose reduction factor. Standard deviation and statistical analyses were calculated by GraphPad Prism program.

\section{FITC labeling of TcPR-10.}

TcPR-10 was labeled using FITC (Sigma) according to Chadha and Das (2006) with modifications. Briefly, $0.5 \mathrm{mg}$ of FITC was dissolved in $50 \mu \mathrm{l}$ of $100 \%$ dimethyl sulfoxide to give a reactive dye concentration of $10 \mathrm{mg} / \mathrm{plate}$. Purified TcPR-10 $(300 \mu \mathrm{g})$ was dissolved in $50 \mathrm{mM}$ carbonate-bicarbonate buffer, pH 9.0. FITC solution was added dropwise to the protein sample and mixed by stirring, and the sample was incubated at $25^{\circ} \mathrm{C}$ in darkness for $1 \mathrm{~h}$. Nonreacted FITC was removed by Sephadex G25 gel filtration and the protein concentration was determined by the Bradford method as described above. An intense fluorescent band under UV light in SDSPAGE gel verified the conjugation between FITC and TcPR10. FITC-labeled TcPR-10 was stored at $4^{\circ} \mathrm{C}$ in the dark until use.

\section{Internalization assays by fluorescence microscopy.}

$M$. perniciosa or $S$. cerevisiae LOG cells were incubated at $25^{\circ} \mathrm{C}$ with FITC-TcPR-10 (8 or $3 \mu \mathrm{g}$, respectively) for different periods $(15 \mathrm{~min}$ to $6 \mathrm{~h}$ ) in the dark in microtiter plates (with or without $0.05 \% \mathrm{NaN}_{3}$, strong inhibitor of metabolism). Low temperature $\left(4^{\circ} \mathrm{C}\right)$ was also used as negative control (inhibition of protein transport). To check for viability and membrane integrity, fungal cells were incubated with both FITC-TcPR-10 and $2 \mu \mathrm{M}$ PI. After incubation intervals ranging from $15 \mathrm{~min}$ to $6 \mathrm{~h}$, FITC- and PI-labeled cells were washed twice in 0.05 $\mathrm{mM} \mathrm{PB}$ and then observed under fluorescence microscope DMRA2 (Leica) attached with FITC and PI filters. Images were captured using $\times 40$ and $\times 100$ objectives under bright field as well as under fluorescent filters using the IM50 software (Leica).

\section{ACKNOWLEDGMENTS}

We thank D. J. Eide and D. J. Thiele for kindly providing yeast strains. The work of S. A. de Melo and A. C. da Silva was supported by the Fundação de Amparo à Pesquisa do Estado da Bahia (FAPESB). M. Brendel holds a FAPESB fellowship. This research was supported by FAPESB, the Conselho Nacional de Desenvolvimento Científico e Tecnológico (CNPq), the International Foundation for Science (IFS), and the Financiadora de Estudos e Projetos (FINEP).

\section{LITERATURE CITED}

Aime, M. C., and Phillips-Mora, W. 2005. The causal agents of witches' broom and frosty pod rot of cacao (chocolate, Theobroma cacao) form a new lineage of Marasmiaceae. Mycologia 97:1012-1022. 
Altschul, S. F., Madden, T. L., Schaffer, A. A., Zhang, J., Zhang, Z., Miller, W., and Lipman, D. J. 1997. Gapped BLAST and PSI-BLAST: A new generation of protein database search programs. Nucleic Acids Res. 25:3389-3402.

Andebrhan, T., Figueira, A., Yamada, M. M., Cascardo, J., and Furtek, D. B. 1999. Molecular fingerprinting suggests two primary outbreaks of witches' broom disease (Crinipellis perniciosa) of Theobroma cacao in Bahia, Brazil. Eur. J. Plant Pathol. 105:167-175.

Bantignies, B., Séguin, J., Muzac, I., Dédaldéchamp, F., Gulick, P., and Ibrahim, R. 2000. Direct evidence for ribonucleolytic activity of a PR10-like protein from white lupin roots. Plant Mol. Biol. 42:871-881.

Blom, N., Gammeltoft, S., and Brunak, S. 1999. Sequence- and structurebased prediction of eukaryotic protein phosphorylation sites. J. Mol. Biol. 294:1351-1362.

Brachmann, C. B., Davies, A., Cost, G. J., Caputo, E., Li, J., Hieter, P., and Boeke, J. D. 1998. Designer deletion strains derived from Saccharomyces cerevisiae S288C: A useful set of strains and plasmids for PCRmediated gene disruption and other applications. Yeast 14:115-132.

Bradford, M. M. 1977. A rapid and sensitive method for the quantification of microgram quantities of protein utilizing the principle of protein-dye binding. Anal. Biochem. 72:248-254.

Breda, C., Sallaud, C., El-Turk, J., BuVard, D., de Kosak, I., Esnault, R., and Kondorosi, A. 1996. Defense reaction in Medicago sativa: A gene encoding a class 10 PR protein is expressed in vascular bundles. Mol. Plant-Microbe Interact. 9:713-719.

Brendel, M., and Haynes, R. H. 1973. Interactions among genes controlling sensitivity to radiation and alkylation in yeast. Mol. Gen. Genet. 125:197-216.

Bufe, A., Spangfort, M. D., Kahlert, H., Schlaak, M., and Becker, W. M. 1996. The major birch pollen allergen, Bet V1, shows ribonuclease activity. Planta 199:413-415.

Burke, D., Dawson, D., and Stearns, T. 2000. Methods in Yeast Genetics. Cold Spring Harbor Laboratory Course Manual. Cold Spring Harbor Laboratory Press, Cold Spring Harbor, NY, U.S.A.

Ceita, G. O., Macêdo, J. N. A., Santos, T. B., Alemanno, L., Gesteira, A. S., Micheli, F., Mariano, A. C., Gramacho, K. P., Silva, D. C., Meinhardt, L., Mazzafera, P., Pereira, G. A. G., and Cascardo, J. C. M. 2007. Involvement of calcium oxalate degradation during programmed cell death in Theobroma cacao tissues triggered by the hemibiotrophic fungus Moniliophthora perniciosa. Plant Sci. 173:106-117.

Chadha, P., and Das, R. H. 2006. A pathogenesis related protein, AhPR10 from peanut: An insight of its mode of antifungal activity. Planta 225:213-222.

Christensen, A. B., Cho, B. H., Naesby, M., Gregersen, P. L., Brandt, J., Madriz-Ordenana, K., Collinge, D. B., and Thordal-Christensen, H. 2002. The molecular characterisation of the two barley proteins establishes the novel PR-17 family of pathogenesis-related protein. Mol. Plant Pathol. 3:134-144.

Colditz, F., Niehaus, K., and Krajinski, F. 2007. Silencing of PR-10-like proteins in Medicago truncatula results in an antagonistic induction of other PR proteins and in an increased tolerance upon infection with the oomycete Aphanomyces euteiches. Planta 226:57-71.

Coleman, S. T., Tseng, E., and Moye-Rowley, W. S. 1997. Saccharomyces cerevisiae basic region-leucine zipper protein regulatory networks converge at the ATR1 structural gene. J. Biol. Chem. 272:23224-23230.

Ekramoddoullah, A. K. M., Davidson, J. J., and Taylor, D. 1998. A protein associated with frost hardiness of western white pine is up-regulated by infection in the white pine blister rust pathosystem. Can. J. For. Res. 28:412-417.

Esnault, R., Buffard, D., Breda, C., Sallaud, C., El Turk, Z. J., and Kondorosi, A. 1993. Pathological and molecular characterization of alfalfa interactions with compatible and incompatible bacteria, Xanthomonas campestris pv. alfalfae and Pseudomonas syringae pv. pisi. Mol. Plant-Microbe Interact. 6:655-664.

Filho, D., Pungartnik, C., Cascardo, J. C. M., and Brendel, M. 2006. Broken hyphae of the basidiomycete Crinipellis perniciosa allow quantitative assay of toxicity. Curr. Microbiol. 52:407-412.

Garcia, O., Macedo, J. N., Tiburcio, R., Zaparoli, G., Rincones, J., Bittencourt, L. M. C., Ceita, G. O., Micheli, F., Gesteira, A., Mariano, A. C., Schiavinato, M. A., Medrano, F. J., Meinhardt, L. W., Pereira, G. A. G., and Cascardo, J. C. M. 2007. Characterization of necrosis and ethylene-inducing proteins (NEP) in the basidiomycete Moniliophthora perniciosa, the causal agent of witches' broom in Theobroma cacao. Mycol. Res. 111:443-455.

Gesteira, A. S., Micheli, F., Carels, N., Da Silva, A. C., Gramacho, K. P., Schuster, I., Macêdo, J. N., Pereira, G. A. G., and Cascardo, J. C. M. 2007. Comparative analysis of expressed genes from cacao meristems infected by Moniliophthora perniciosa. Ann. Bot. 100:129-140.

Gömpel-Klein, P., and Brendel, M. 1990. Allelism of SNQ1 and ATR1, genes of the yeast Saccharomyces cerevisiae required for controlling sensitivity to 4-nitroquinoline-N-oxide and aminotriazole. Curr. Genet. 18:93-96

Gounalaki, N., and Thireos, G. 1994. Yap1p, a yeast transcriptional activator that mediates multidrug resistance, regulates the metabolic stress response. EMBO (Eur. Mol. Biol. Organ.) J. 13:4036-4041.

He, X. J., and Fassler, J. S. 2005. Identification of novel Yap1p and Skn7p binding sites involved in the oxidative stress response of Saccharomyces cerevisiae. Mol. Microbiol. 58:1454-1467.

Hertle, K., Haase, E., and Brendel, M. 1991. The SNQ3 gene of Saccharomyces cerevisiae confers hyperresistance to several functionally unrelated chemicals. Curr. Genet. 19:429-433.

Kolaczkowska, A., Kolaczkowski, M., Goffeau, A., and Moye-Rowley, W. S. 2008. Compensatory activation of the multidrug transporters Pdr5p, Snq2p, and Yorlp by Pdr1p in Saccharomyces cerevisiae. FEBS (Fed. Eur. Biochem. Soc.) Lett. 582:977-983.

Laemmli, U. K. 1970. Cleavage of structural protein during the assembly of the head of bacteriophage T4. Nature 227:680-685.

Lerouge, P., and Faye, L. 1996. Recent developments in structural analysis of N-glycans from plant glycoprotéins. Plant Physiol. Biochem. 34:263271.

Liu, J.-J., and Ekramoddoullah, A. K M. 2006. The family 10 of plant pathogenesis-related proteins: Their structure, regulation, and function in response to biotic and abiotic stresses. 2006. Physiol. Mol. Plant Pathol. 68:3-13

Liu, J.-J. Ekramoddoullah, A. K. M., and Yu, X. 2003. Differential expression of multiple PR10 proteins in western white pine following wounding, fungal infection and cold-hardening. Physiol. Plant. 119:544-553.

Liu, J.-J., Ekramoddoullah, A. K., Piggott, N., and Zamani, A. 2005. Molecular cloning of a pathogen/wound-inducible PR10 promoter from Pinus monticola and characterization in transgenic Arabidopsis plants. Planta 221:159-169.

Liu, X., Huang, B., Lin, J., Fei, J., Chen, Z., Pang, Y., Sun, X., and Tang, K. A. 2006. Novel pathogenesis-related protein (SsPR10) from Solanum surattense with ribonucleolytic and antimicrobial activity is stress- and pathogeninducible. J. Plant Physiol. 163:546-56.

Mauch, F., Mauch-Mani, B., and Boller, T. 1988. Antifungal hydrolases in pea tissue. Inhibition of fungal growth by combinations of chitinase and $\beta$-1,3-glucanase. Plant Physiol. 88:936-942.

Maximova, S. N., Marelli, J. P., Young, A., Pishak, S., Verica, J. A., and Guiltinan, M. J. 2006. Over-expression of a cacao class I chitinase gene in Theobroma cacao L. enhances resistance against the pathogen, Colletotrichum gloeosporioides. Planta 224:740-749.

McGee, J. D., Hamer, J. E., and Hodges, T. K. 2001. Characterization of a PR-10 pathogenesis-related gene family induced in rice during infection with Magnaporthe grisea. Mol. Plant-Microbe Interact. 14:877-886.

Meinhardt, L. W., Bellato, C. M., Rincones, J., Azevedo, R. A., Cascardo, J. C. M., and Pereira, G. A. G. 2006. In vitro production of biotrophiclike cultures of Crinipellis perniciosa, the causal agent of witches' broom disease of Theobroma cacao. Curr. Microbiol. 52:191-196.

Miyahara, K., Hirata, D., and Miyakawa, T. 1996. yAP-1- and yAP-2-mediated, heat-shock-induced transcriptional activation of the multidrug resistance $\mathrm{ABC}$ transporter genes in Saccharomyces cerevisiae. Curr. Genet. 29:103-105.

Morgensen, J. E., Wimmer, R., Larsen, J. N., Spangfort, M. D., and Otzen, D. E. 2002. The major birch allergen, Bet v 1, shows affinity for a broad spectrum of physiological ligands. J. Biol. Chem. 277:23684-23692

Neuhoff, V., Arold, N., Taube, D., and Ehrhardt, W. 1988. Improved staining of proteins in polyacrylamide gels including isoelectric focusing gels with clear background at nanogram sensitivity using Coomassie Brilliant Blue G-250 and R-250. Electrophoresis 9:255-262.

Park, C. J., Kim, K. J., Shin, R., Park, J. M., Shin, Y. C., and Paek, K. H. 2004. Pathogenesis-related protein 10 isolated from hot pepper functions as a ribonuclease in an antiviral pathway. Plant J. 37:186-198.

Pirovani, C. P., Carvalho, H. A. S., Machado, R. C. R, Gomes, D. S., Alvim, F. C., Pomella, A. W. V., Gramacho, K. P., Cascardo, J. C. M., Pereira, G. A. G., and Micheli, F. 2008. Protein extraction for proteome analysis from cacao leaves and meristems, organs infected by Moniliophthora perniciosa, the causal agent of the witches' broom disease. Electrophoresis 29:2391-2401.

Pungartnik, C., Picada, J., Brendel, M., and Henriques, J. A. P. 2002. Further phenotypic characterisation of pso mutants of Saccharomyces cerevisiae with respect to DNA repair and response to oxidative stress. Genet. Mol. Res. 1:79-89.

Rodrigues-Pousada, C. A., Nevitt, T., Menezes, R., Azevedo, D., Pereira, J., and Amaral, C. 2004. Yeast activator proteins and stress response: An overview. FEBS (Fed. Eur. Biochem. Soc.) Lett. 567:80-85.

Samanani, N., Liscombe, D. K., and Facchini, P. J. 2004. Molecular cloning and characterization of norcoclaurine synthase, an enzyme catalyzing the first committed step in benzylisoquinoline alkaloid biosynthesis. Plant J. 40:302-313. 
Santos, R. X., Melo, S. C. O., Cascardo, J. C. M., Brendel, M., and Pungartnik, C. 2008. Carbon source-dependent variation of acquired mutagen resistance of Moniliophthora perniciosa: Similarities in natural and artificial systems. Fungal Genet. Biol. 45:851-860.

Scarpari, L. M., Meinhardt, L. W., Mazzafera, P., Pomella, A. W. V., Schiavinato, M. A., and Cascardo, J. C. M. 2005. Biochemical changes during the development of witches' broom: The most important disease of cocoa in Brazil caused by Crinipellis perniciosa. J. Exp. Bot. 56:865-877.

Sikorski, R. S., and Hieter, P. 1989. A system of shuttle vectors and yeast host strains designed for efficient manipulation of DNA in Saccharomyces cerevisiae. Genetics 122:19-27.

Silva, S. D., Luz, E. D. M. N., Almeida, O. C., Gramacho, K., and Bezerra, J. L. 2002. Redescrição da sintomatologia causada por Crinipellis perniciosa em cacaueiro. Agrotropica 1:1-23.

Swoboda, I., Hoffmann-Sommergruber, K., O’Riordain, G., Scheiner, O., Heberle-Bors, E., and Vincente, O. 1996. Bet v 1 proteins, the major birch pollen allergens and members of a family of conserved pathogenesisrelated proteins, show ribonuclease activity in vitro. Physiol. Plant. 96:433-438.

Tanabe, S., Okada, M., Jikumaru, Y., Yamane, H., Kaku, H., Shibuya, N., and Minami, E. 2006. Induction of resistance against rice blast fungus in rice plant treated with a potent elicitor $\mathrm{N}$-acetylchitooligosaccaride. Biosci. Biotechnol. Biochem. 70:1599-1605.

Thevissen, K., Terras, F. R., and Broekaert, W. F. 1999. Permeabilization of fungal membranes by plant defensins inhibits fungal growth. Appl. Environ. Microbiol. 65:5451-5458.

Thompson, J. D., Higgins, D. G., and Gibson, T. J. 1994. CLUSTAL W: Improving the sensitivity of progressive multiple sequence alignment through sequence weighting, position-specific gap penalties and weight matrix choice. Nucleic Acids Res. 22:4673-4680. van Loon, L. C., and Van Serien, E. A. 1999. The family of pathogenesisrelated proteins. Physiol. Mol. Plant Pathol. 55:85-97.

van Loon, L. C., Pierpoint, W. S., Boller, T., and Conejero, V. 1994. Recommendation for naming plant pathogenesis-related proteins. Plant Mol. Biol. Rep. 12:245-264.

van Loon, L. C., Rep, M., and Pieterse, C. M. 2006. Significance of inducible defense-related proteins in infected plants. Annu. Rev. Phytopathol. 44:135-162.

Walter, M. H., Liu, J.-W., Grand, C., Lamb, C. J., and Hess, D. 1990. Bean pathogenesis-related (PR) proteins deduced from elicitor-induced transcripts are members of a ubiquitous new class of conserved PR proteins including pollen allergens. Mol. Gen. Genet. 222:353-360.

Xu, P., Blancaflor, E. B., and Roossinck, M. J. 2003. In spite of induced multiple defense responses, tomato plants infected with cucumber mosaic virus and D satellite RNA succumb to systemic necrosis. Mol. Plant-Microbe Interact. 16:467-476.

Zhou, X. J, Shan, L., Xu, Y. H., Wang, J. W., and Chen, X. Y. 2002. A cotton cDNA (GaPR-10) encoding a pathogenesis-related 10 protein with in vitro ribonuclease activity. Plant Sci. 162:629-636.

Ziadi, S., Poupard, P., Brisset, M. N., Paulin, J. P., and Simoneau, P. 2001. Characterization in apple leaves of two subclasses of PR-10 transcripts inducible by acibenzolar-S-methyl, a functional analogue of salicylic acid. Physiol. Mol. Plant Pathol. 59:33-43.

\section{AUTHOR-RECOMMENDED INTERNET RESOURCES}

Food and Agriculture Organization website: www.fao.org Center for Biological Sequence Analysis NetPhos server: www.cbs.dtu.dk/services/NetPhos 